DOI: 10.17707/AgricultForest.64.2.12

\author{
Ebrahim BROOSHKEH, Reza SOKOUTI, \\ Mahmoud ARAB KHEDRI, Saeed NABI PEY LASHKARIAN ${ }^{1}$
}

\title{
COMPARATIVE EFFICACY OF SOME EMPIRICAL MODELS TO ESTIMATE SEDIMENT YIELD IN SMALL CATCHMENTS
}

\begin{abstract}
SUMMARY
Empirical models have been developed to estimate erosion for a certain area and their calibration is essential for use in off-site conditions. Empirical modeling with high accuracy and efficiency for estimating sediment load can lead to better estimates of sediment load, resulting in a more appropriate design of soil and water conservation practices. The aim of this study was to compare the efficiency of FSM, MPSIAC and PSIAC models in estimating erosion and sedimentation. In this study, 10 small watersheds were selected with areas between 14.3 and 556 hectares as the field of research. The model parameters were determined using available maps, satellite images and field operations. The amount of watershed sediment was estimated using empirical models described above. Observed sediment was calculated by determining sediment volume in check dam by field method. The minimum, average and maximum observed sediment were respectively $0.41,0.82$ and $1.18 \mathrm{~m}^{3} \mathrm{ha}^{-1}$ year ${ }^{-1}$. The correlation coefficients between the observed sediment and the estimated sediment by the empirical models of FSM, MPSIAC and PSIAC, respectively, were 0.56, 0.47 and 0.54. The estimated sediment data of the empirical models were compared with the observed sediment data of the relative error test. Values of the relative error estimated for FSM, MPSIAC and PSIAC models were 38.67, 1.22 and 2.35. Efficiency index of Nash and Sutcliffe for FSM, PSIAC and MPSIAC models were, respectively, $-17386.37,-45.46$ and -11.48 . These results indicated that the FSM model compared with the other two models had more errors, and this model with the baseline coefficients has no efficiency to estimate the sediment of small watersheds, and the two PSIAC and MPSIAC models also faced with sediment overestimation, but the MPSIAC model showed relatively acceptable results.
\end{abstract}

Keywords: Sediment, Empirical Models, FSM, MPSIAC, Small Watersheds

\section{INTRODUCTION}

Soil erosion and sediment yield is one of the main challenges in Iran, and quantity estimation of them is an important issue (Amini et al., 2014). In the

1 Ebrahim Brooshkeh (corresponding author: e.brooshkeh@gmail.com), Reza Sokouti, Agricultural and Natural Resources Research Center, West Azarbaijan, Agricultural Research, Education and Extension Organization (AREEO), Orumieh, IRAN. Mahmoud Arab Khedri, Saeed Nabi Pey Lashkarian, Soil Conservation and Watershed Management Research Institute, Agricultural Research, Education and Extension Organization (AREEO), Tehran, IRAN

Notes: The authors declare that they have no conflicts of interest. Authorship Form signed online. 
current situation, statistics and information are collected by data acquisition from sediment measurement in stations of large-scale watersheds. The results obtained from the data are not easily generalizable to the small sub-basins and watersheds. On the other hand, enough information is not available on consistent rate of empirical methods to estimate erosion and sedimentation concerning condition of watersheds in the country, and this leads to distrust the statistics and information about erosion and the estimated sediment in the basins. Based on the evidences, the greatest difficulty caused by sedimentation is related to small-scale watersheds. Lack of appropriate data on sediment for small watersheds has created many problems for watershed management experts. One way is to use empirical models to estimate soil erosion and sediment yield.

All these models consist of empirical coefficients and constants, which may not be suitable for other regions (Hadley, 1985) so that Pourkarimi et al. (2017) recommended that both the EPM and MPSIAC models were created in countries with climates and geology attributes that differ from those of Iran. Hence, the coefficients and factors affecting erosion do not correspond precisely to the conditions in Iran. Mahmoudzadeh (2002) measured the specific sediment yield on 19 small watersheds with end dam in New South Wales, Australia, and considered the trapping coefficient due to sediment outflow; the age of structure was 4 to 31 years. Martin-Rosales et al (2003) measured sediments 107 of Gabion, concrete, stone and cement dams in a semi-arid region with Mediterranean climate in the south of Spain. Verstraeten et al. (2003) provided a quantitative model of FSM (Factorial Scoring Model) for the first time in Spain, and used five factors of topography, lithology, basin shape, ditch and vegetation to calculate sediment yield in catchments. De Vente et al. (2005) calibrated the FSM model for the sub watersheds and resolved existing problems. Haregeweyn et al. (2005) also evaluated the FSM and PSIAC models in Tigre region of Ethiopia, and concluded that the FSM model has less fit with the observed values than the PSIAC model. Khodami (2005) used for the first time this model in Iran on Lateshur watershed, Northeast of Pakdasht, and found that the FSM model has more suitable match than the PSIAC model. Gholami (2013) by applying the FSM and MPSIAC models in Nahand watershed of East Azerbaijan, Iran, and reported the sediment values respectively equal to 3.27 and 4.18 tons per hectare per year, representing the superiority of the FSM model compared to MPSIAC model in this research. Neil (1988) through farm dam in the outlet of fourteen small watersheds at River Valley at Yasi found that the sediment value varies from six to $54 \mathrm{~m}^{3} / \mathrm{km}^{2} /$ year. Management factors in sediment yield are more crucial than morphological parameters. De Vente et al. (2006) in another study in Italy, added landslide factor to the FSM, the results of this study compared to the previous method showed better agreement with measured sediment value. Nichols (2006) in southern Arizona, the United States, measured sediment in eight sub-basins, with an average of 30 to 47 year life of the dams. Hashemi (2010) assessed sediment volume deposited in the reservoir of nine soil dams in Semnan province, Iran, which based on the evidence, there was no overflow of 
sediment; the lifespan of the structures was 14 years. Mohamadiha (2011) used the FSM model in Eivaneki watershed in Iran and compared the results with data obtained from the MPSIAC models and simulators, and concluded that the data of FSM model are more consistent compared to the MPSIAC model. Atapourfard (2012) using the FSM model on Tehran watershed found that the efficiency was 0.62 and the PRMSE was equal to 0.27. Gusman 2012 estimated the FSM of the sediment load in upper Liobregat watershed greater than the actual value.

This study was carried out to evaluate the efficiency of the empirical models of FSM, MPSIAC and PSIAC to determine their accuracy in estimating sediment of small watersheds with an area up to 10 square kilometers.

\section{MATERIAL AND METHODS}

This study was carried out in West Azerbaijan province that is located at latitude $38^{\circ} 58^{\prime}$ to $39^{\circ} 47^{\prime} \mathrm{N}$ and longitude $44^{\circ} 14$ to $47^{\circ} 17^{\prime \prime} \mathrm{E}$ in Iran. Based on data achieved from 10 small watersheds with an area between 14.35 and 556 hectares. The study basins had a variety of slope, land use, topography and geology.

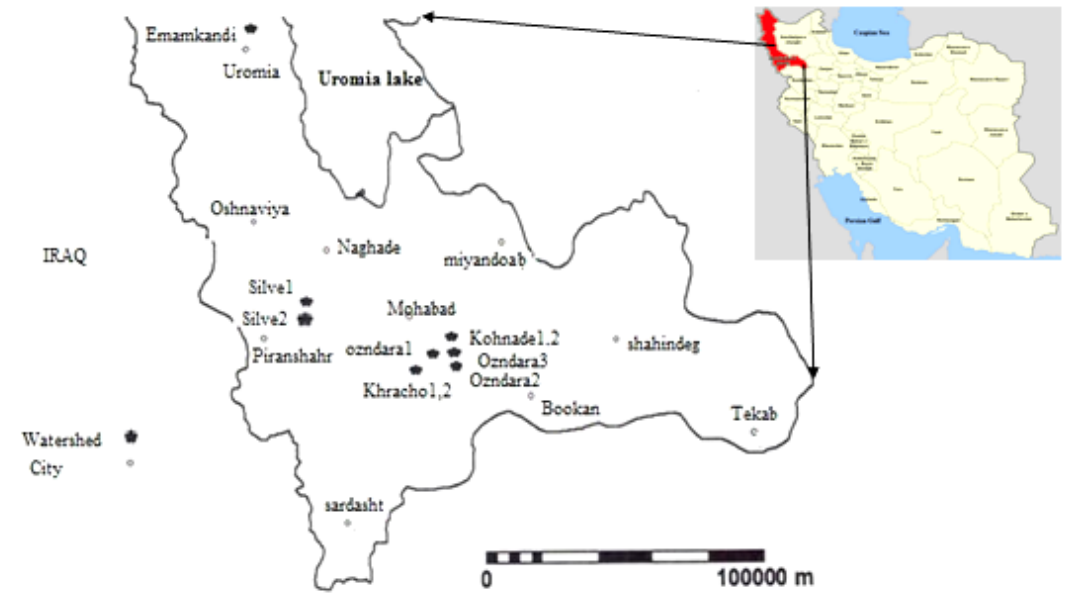

$3953972 \underset{411543}{L}$

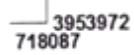

\section{Fig. 1: Location of the study area}

The sedimentation volumes were measured in reservoirs of 53 small dams, which had sufficient volume for trapping sediment. The sediment control structures were in kinds of concrete, stone or mortar and Gabion sometimes; there was a check dam in a number of watersheds and over 14 small dams in some of them, which had been constructed in continuous across the drainage path and had enough space for trapping sediment behind the dams.

The steps of the research were as follows:

- First, selection of 10 small watersheds having check dam with a minimum of 10 years construction history, 
- Studies on physiographic features, lithology, soil science, meteorology, hydrology, topography, vegetation, land use and erosion for each of the watershed,

- Scoring the model factors using various tools, including previous studies, satellite images, aerial photos, topographic maps, field operations and table on how to score the factors in the FSM, MPSIAC and PSIAC models.

Table 1: How to scoring factors in the FSM model (Verstraeten et al., 2003)

\begin{tabular}{|c|c|c|}
\hline Factor & Score & Description \\
\hline \multirow[t]{3}{*}{ Topography } & 1 & $\begin{array}{l}\text { Very gentle slopes near reservoir and main } \\
\text { rivers; elevation difference !200 m within } 5 \mathrm{~km}\end{array}$ \\
\hline & 2 & $\begin{array}{l}\text { Moderate slopes near reservoir and main rivers; } \\
\text { elevation difference } 200-500 \mathrm{~m} \text { within } 5 \mathrm{~km}\end{array}$ \\
\hline & 3 & $\begin{array}{l}\text { Steep slopes near reservoir and main rivers; } \\
\text { elevation difference } \mathrm{O} 500 \mathrm{~m} \text { within } 5 \mathrm{~km}\end{array}$ \\
\hline \multirow[t]{3}{*}{$\begin{array}{r}\text { Vegetation } \\
\text { cover }\end{array}$} & 1 & $\begin{array}{l}\text { Good contact cover of the soil (O75\% surface } \\
\text { protected) }\end{array}$ \\
\hline & 2 & $\begin{array}{l}\text { Moderate contact cover (25-75\% protected } \\
\text { surface) }\end{array}$ \\
\hline & 3 & Poor contact cover (25\% protected) \\
\hline \multirow[t]{3}{*}{ Gullies } & 1 & Bank and ephemeral gullies are very rare \\
\hline & 2 & $\begin{array}{l}\text { Few bank and/or ephemeral gullies can be } \\
\text { observed }\end{array}$ \\
\hline & 3 & $\begin{array}{l}\text { Many bank and/or ephemeral gullies can be } \\
\text { observed }\end{array}$ \\
\hline \multirow[t]{3}{*}{ Lithology } & 1 & $\begin{array}{l}\text { Dominant limestone, sandstone or } \\
\text { conglomerate(low weathering degree) }\end{array}$ \\
\hline & 2 & $\begin{array}{l}\text { Dominant Neogene sedimentary deposits } \\
\text { (gravels, etc.) }\end{array}$ \\
\hline & 3 & $\begin{array}{l}\text { Strongly weathered (loose) material loams and/or } \\
\text { marls }\end{array}$ \\
\hline \multirow[t]{3}{*}{$\begin{array}{l}\text { Watershed } \\
\text { shape }\end{array}$} & 1 & $\begin{array}{l}\text { Elongated basin shape with one main river } \\
\text { channel draining to the reservoir. No significant } \\
\text { direct runoff }\end{array}$ \\
\hline & 2 & $\begin{array}{l}\text { Between elongated and (semi-) circular basin } \\
\text { shape }\end{array}$ \\
\hline & 3 & $\begin{array}{l}\text { (Semi-) circular basin shape with many rivers } \\
\text { draining into the reservoir and/or much direct } \\
\text { runoff from } \\
\text { hill slopes to the reservoir }\end{array}$ \\
\hline
\end{tabular}


- Sediment yield in the watersheds was determined using equation (1) in the FSM model.

$$
S S Y=4193 A^{-0.44}+7.77(\text { FSMIndex })-310.99 \quad \text { Equation (1) }
$$

Which, SSY: specific suspended-sediment yield $\left(\mathrm{t} / \mathrm{km}^{2}\right)$, A: area $\left(\mathrm{km}^{2}\right)$ and FSM Index: obtained by multiplying the five factors of the model.

- The range of scores for nine parameters of the PSIAC and MPSIAC models was determined as Table 2 using a pointed tools, field studies and expert work.

Table 2: The range of scores for the parameters of PSIAC and MPSIAC models ( Johnson and Gebhardt, 1982)

\begin{tabular}{|l|c|l|l|}
\hline $\begin{array}{l}\text { Erosion } \\
\text { factors }\end{array}$ & Psiac & Mpsiac & parameters \\
\hline lithology & $0-10$ & Y1=X1 & X1=Geological erosion index \\
\hline Soil & $0-10$ & Y2=16.67X2 & X2=Soil erodibility factor \\
\hline climate & $0-10$ & Y3=0.2X3 & $\begin{array}{l}\text { X3=6-hour rainfall with a 2-year } \\
\text { return period }\end{array}$ \\
\hline runoff & $0-10$ & Y4=0.006R+10Qp & $\begin{array}{l}\text { Qp= annual specific Debi } \\
\left.\mathrm{m}^{3} / \mathrm{skm}^{2}\right) \mathrm{R}=\text { annual of runoff } \\
\text { Height }\left(\mathrm{mm}^{3}\right)\end{array}$ \\
\hline topography & $0-20$ & $\mathrm{Y} 5=0.33 \mathrm{X} 5$ & $\begin{array}{l}\mathrm{X} 5=\text { Percentage of the average } \\
\text { basin slope }\end{array}$ \\
\hline vegetation & $-10-(+10)$ & $\mathrm{Y} 6=0.2 \mathrm{X} 6$ & $\begin{array}{l}\mathrm{X} 6=\text { Percentage of land without } \\
\text { vegetation }\end{array}$ \\
\hline $\begin{array}{l}\text { Land use } \\
\text { vurface } \\
\text { erosion }\end{array}$ & $0-25$ & $\mathrm{Y} 8=0.25 \mathrm{X} 8$ & $\begin{array}{l}\mathrm{X} 7=\text { Percentage of vegetation } \\
\text { cover }\end{array}$ \\
\hline $\begin{array}{l}\text { Channel } \\
\text { erosion }\end{array}$ & $0-25$ & $\mathrm{Y} 9=1.67 \mathrm{X} 9$ & $\begin{array}{l}\mathrm{X} 9=\text { Gutal surface soil factor } \\
\text { scoring in BLM* }\end{array}$ \\
\hline
\end{tabular}

*BLM: Breau of Land Management (Refahi 2006)

- In the PSIAC model, the rate of annual sediment yield was calculated after scoring for each factor and the sum of these scores using equation (2),

Qs $=38.77 \mathrm{e}^{0.0353 \mathrm{R}}$

Equation (2)

Where: Qs: the rate of sediment yield $\left(\mathrm{m}^{3} / \mathrm{km}^{2} /\right.$ year), and R: the sediment yield degree.

-In the MPSIAC model, equation (3) was used to estimate the sediment.

Qs $=0.253 \mathrm{e}^{0.036 \mathrm{R}}$

Equation (3) 
-The observed sediment in each watershed was determine via the sediment volume by measuring the sediment of the reservoirs accumulated in behind the check dam.

-The estimated sediment of three FSM, MPSIAC and PSIAC models was investigated and analyzed with measured sediment from the sediment measurement in dams, by the statistical method of relative error in equation (4) (Moore et al., 2009).

$$
\sigma x=\frac{\Delta \mathrm{x}}{\mathrm{x}}=\frac{\mathrm{xo}-\mathrm{x}}{\mathrm{x}}=\frac{\mathrm{xo}}{\mathrm{x}}-1
$$

Equation (4)

Where: $\mathrm{X}_{0}=$ estimated value, $\mathrm{X}=$ observed value and $\delta_{\mathrm{X}}=$ relative error

- Nash and Sutcliffe method was used to evaluate the efficiency of model, equation (5) (Nash and Sutcliffe 1970).

$$
M E=1-\frac{\sum_{i=1}^{n}\left(Q_{i}-P i\right)^{2}}{\sum_{i=1}^{n}\left(Q_{i}-\bar{Q}\right)^{2}}
$$

Equation (5)

Where: ME: model efficiency, Qi: measured values, Q̄: average measured values, $\mathrm{Pi}$ : predicted values and $\mathrm{n}$ : number of samples used

\section{RESULTS AND DISCUSSION}

Some of the features of study areas including watershed size, check dam age, type of land use, weighted average slope, annual rainfall and basin lithology have been presented in Table 3 .

\begin{tabular}{|c|c|c|c|c|c|c|}
\hline $\begin{array}{c}\text { small } \\
\text { catchments }\end{array}$ & $\begin{array}{c}\text { Area } \\
\text { (ha) }\end{array}$ & $\begin{array}{c}\begin{array}{c}\text { Age } \\
\text { (year) }\end{array} \\
\end{array}$ & Land use & $\begin{array}{c}\text { Slope } \\
\text { (\%) }\end{array}$ & $\begin{array}{l}\text { Precipitation } \\
(\mathrm{mm})\end{array}$ & Litology \\
\hline Emamkandi & 174.03 & 12 & Rangeland & 44.94 & $346 / 7$ & $\begin{array}{c}\text { Limestone, } \\
\text { dolomite, shale, }\end{array}$ \\
\hline Silve1 & 79.00 & 13 & $\begin{array}{l}\text { Rangeland \& } \\
\text { dry farming }\end{array}$ & 16.92 & 549 & $\begin{array}{l}\text { Limestone, old } \\
\text { terraces }\end{array}$ \\
\hline Silve2 & 78.00 & 12 & $\begin{array}{l}\text { Rangeland \& } \\
\text { dry farming }\end{array}$ & 15.70 & 549 & Limestone, \\
\hline Ozondara1 & 14.35 & 11 & $\begin{array}{l}\text { Rangeland \& } \\
\text { dry farming }\end{array}$ & 35.11 & 496 & $\begin{array}{c}\text { Phyllite, gneiss, } \\
\text { volcanic rocks }\end{array}$ \\
\hline Ozondara2 & 104.70 & 11 & $\begin{array}{c}\text { Rangeland \& } \\
\text { dry farming }\end{array}$ & 38.85 & 496 & $\begin{array}{l}\text { rhyolite } \\
\end{array}$ \\
\hline Ozondara3 & 129.04 & 11 & Rangeland & 40.47 & 496 & $\begin{array}{c}\text { Rhyolite, red } \\
\text { sandstone, siltstone }\end{array}$ \\
\hline Kohnede1 & 556.00 & 10 & $\begin{array}{l}\text { Rangeland \& } \\
\text { dry farming }\end{array}$ & 32.62 & 496 & rhyolite \\
\hline Kohnede2 & 408.00 & 10 & $\begin{array}{l}\text { Rangeland \& } \\
\text { dry farming }\end{array}$ & 30.74 & 496 & $\begin{array}{c}\text { Rhyolite, red } \\
\text { sandstone, siltstone, }\end{array}$ \\
\hline Khracho1 & 97.06 & 10 & $\begin{array}{l}\text { Rangeland \& } \\
\text { dry farming }\end{array}$ & 37.24 & 496 & gneiss, granite \\
\hline Khracho2 & 118.75 & 10 & $\begin{array}{l}\text { Rangeland \& } \\
\text { dry farming }\end{array}$ & 36.87 & 496 & gneiss, granite \\
\hline
\end{tabular}

Table 3: General characteristics of the study area 
The scores of five factors of the FSM model were determined using various tools including satellite images, aerial photos, topographic maps, field operations, integrating mentioned data and information of Table 1. The FSM model applying equation (1) with the unit of ton/ha/year estimated the sediment and then was converted to $\mathrm{m}^{3} / \mathrm{ha} /$ year based on the specific weight of sediment (Table 4).

Table 4: Final scores of five factor and sediment yield calculation results by FSM method

\begin{tabular}{lcccccccccc}
\hline parameters & Emamkandi & Silve1 & Silve2 & Ozondara1 & Ozondara2 & Ozondara3 & Kohnede1 & Kohnede2 & Khracho1 & Khracho2 \\
\hline Topography & 2.91 & 2.02 & 1.95 & 2.74 & 2.88 & 2.29 & 2.85 & 2.75 & 2.84 & 2.84 \\
vegetation cover & 2.00 & 2.00 & 2.00 & 2.00 & 2.00 & 2.00 & 2.52 & 2.57 & 2.60 & 2.67 \\
Gulli & 1.00 & 1.00 & 1.00 & 1.00 & 1.00 & 1.00 & 2.00 & 2.00 & 3.00 & 3.00 \\
Litology & 1.85 & 1.00 & 1.00 & 2.00 & 2.00 & 1.84 & 1.48 & 1.29 & 2.00 & 2.00 \\
Shape & 2.00 & 1.00 & 1.00 & 3.00 & 2.00 & 2.00 & 2.00 & 2.00 & 2.00 & 2.00 \\
Area(ha) & 1.82 & 0.79 & 0.78 & 0.14 & 1.04 & 1.29 & 5.56 & 4.08 & 0.97 & 1.12 \\
FSM(Index) & 21.53 & 4.04 & 3.90 & 32.88 & 23.04 & 21.49 & 41.03 & 36.60 & 88.60 & 90.99 \\
Predicted SY (ton/ha/y) & 30.92 & 43.83 & 44.07 & 100.25 & 40.07 & 36.23 & 19.18 & 22.07 & 40.70 & 37.06 \\
Predicted SY $\left(\mathrm{m}^{3} / \mathrm{ha} / \mathrm{y}\right)$ & 23.35 & 31.31 & 33.90 & 38.75 & 26.37 & 25.88 & 14.31 & 15.12 & 29.72 & 28.08
\end{tabular}

According to Table 4, the average estimated sediment from the FSM model in the study watersheds was $30.30 \pm 17.07 \mathrm{~m}^{3}$. The minimum observed sediment was $13.14 \mathrm{~m}^{3}$ and the maximum value was $38.75 \mathrm{~m}^{3}$. Nine parameters of the PSIAC model and the amount of sediment $\left(\mathrm{m}^{3} / \mathrm{ha} /\right.$ year) have been shown in Table 5.

Table 5: Final scores of nine factors and sediment yield calculation results by PSIAC method

\begin{tabular}{|l|c|c|c|c|c|c|c|c|c|c|}
\hline parameters & Emamkandi & $\begin{array}{c}\text { Silve } \\
1\end{array}$ & $\begin{array}{c}\text { Silve } \\
\text { lithology }\end{array}$ & $\begin{array}{c}\text { Ozondara } \\
1\end{array}$ & $\begin{array}{c}\text { Ozondara } \\
2\end{array}$ & $\begin{array}{c}\text { Ozondara } \\
3\end{array}$ & $\begin{array}{c}\text { Kohnede } \\
1\end{array}$ & $\begin{array}{c}\text { Kohnede } \\
2\end{array}$ & $\begin{array}{c}\text { Khracho } \\
1\end{array}$ & $\begin{array}{c}\text { Khracho } \\
2\end{array}$ \\
\hline Soil & 4.5 & 6.5 & 6.5 & 4.5 & 5.5 & 5.0 & 4.2 & 3.6 & 5.3 & 5.2 \\
\hline climate & 3.0 & 2.0 & 2.0 & 2.5 & 2.4 & 2.5 & 2.0 & 2.0 & 2.5 & 2.4 \\
\hline runoff & 8.0 & 5.5 & 5.0 & 7.0 & 8.5 & 8.0 & 6.5 & 7.0 & 6.0 & 6.0 \\
\hline topograghy & 16.0 & 7.0 & 7.0 & 11.0 & 12.0 & 13.0 & 12.0 & 11.0 & 13.0 & 12.7 \\
\hline vegetation & 1.0 & 2.0 & 2.0 & 3.0 & 3.0 & 3.0 & 3.0 & 3.0 & 3.0 & 3.0 \\
\hline Land use & 2.0 & 5.0 & 5.0 & 4.0 & 4.0 & 4.0 & 4.0 & 4.0 & 6.0 & 6.0 \\
\hline Surface erosion & 7.0 & 7.5 & 7.5 & 9.0 & 10.0 & 9.5 & 8.5 & 8.5 & 11.0 & 12.0 \\
\hline Channel erosion & 3.0 & 3.0 & 3.0 & 6.0 & 4.0 & 4.0 & 6.0 & 5.0 & 7.0 & 7.0 \\
\hline Sediment Rate & 49.3 & 41.6 & 41.0 & 52.5 & 53.9 & 53.0 & 50.2 & 48.1 & 59.8 & 60.4 \\
\hline $\begin{array}{l}\text { Predicted SY } \\
\mathrm{m}^{3} / \mathrm{km}{ }^{2} / \mathrm{y}\end{array}$ & 226.6 & 171.8 & 168.2 & 253.9 & 267.0 & 259.0 & 233.7 & 216.9 & 329.3 & 366.9 \\
\hline $\begin{array}{l}\text { Predicted SY } \\
\mathrm{m}^{3} / \mathrm{ha} / \mathrm{y}\end{array}$ & 2.2 & 1.72 & 1.68 & 2.54 & 2.67 & 2.59 & 2.34 & 2.17 & 3.29 & 3.37 \\
\hline
\end{tabular}


In the PSIAC model the minimum, average and maximum estimated sediment were, respectively, $1.67,2.46$ and $3.37 \mathrm{~m}^{3} /$ ha/year $( \pm 0.57)$. The estimated values have three times overestimation compared with the observational data. Skewness of data for the observed values was -0.08 , and for the estimated data was 0.29 , and correlation coefficient among the sediment data estimated from model and the observational data was 0.54. Nine parameters of the MPSIAC model and the amount of sediment $\left(\mathrm{m}^{3} / \mathrm{ha} / \mathrm{year}\right)$ are found in Table 6.

Table 6: Final scores of nine factors and sediment yield calculation results by MPSIAC method

\begin{tabular}{|c|c|c|c|c|c|c|c|c|c|c|}
\hline parameters & Emamkandi & $\begin{array}{c}\text { Silve } \\
1\end{array}$ & $\begin{array}{c}\text { Silve } \\
2\end{array}$ & $\begin{array}{c}\text { Ozondara } \\
1\end{array}$ & \begin{tabular}{|c} 
Ozondara \\
2
\end{tabular} & \begin{tabular}{|c|} 
Ozondara \\
3
\end{tabular} & $\begin{array}{c}\text { Kohnede } \\
1\end{array}$ & \begin{tabular}{|c|} 
Kohnede \\
2
\end{tabular} & \begin{tabular}{|c|} 
Khracho \\
1
\end{tabular} & $\begin{array}{c}\text { Khracho } \\
2\end{array}$ \\
\hline lithology & 4.82 & 3.08 & 3.00 & 5.50 & 5.50 & 5.05 & 4.17 & 3.60 & 5.26 & 5.29 \\
\hline Soil & 2.33 & 2.17 & 2.17 & 3.00 & 3.00 & 3.00 & 3.17 & 3.17 & 1.67 & 1.67 \\
\hline climate & 2.60 & 3.20 & 3.20 & 2.60 & 2.60 & 2.60 & 2.40 & 2.40 & 2.80 & 2.80 \\
\hline runoff & 8.66 & 6.57 & 6.31 & 8.09 & 9.04 & 8.52 & 6.19 & 6.88 & 7.08 & 7.08 \\
\hline topograghy & 14.80 & 5.60 & 5.20 & 11.60 & 12.80 & 13.40 & 10.80 & 10.13 & 12.28 & 12.16 \\
\hline vegetation & 3.60 & 6.40 & 6.10 & 6.80 & 7.60 & 7.30 & 6.74 & 7.20 & 7.50 & 7.40 \\
\hline Land use & 10.58 & 13.20 & 12.52 & 13.82 & 15.25 & 14.59 & 14.12 & 14.52 & 14.89 & 14.76 \\
\hline Surface erosion & 5.20 & 6.20 & 6.40 & 7.60 & 7.40 & 7.00 & 8.60 & 8.40 & 9.00 & 9.60 \\
\hline Channel erosion & 1.67 & 1.67 & 1.67 & 3.34 & 1.67 & 1.67 & 5.01 & 5.01 & 6.68 & 6.68 \\
\hline Sediment Rate & 54.26 & 48.09 & 46.57 & 62.35 & 64.86 & 63.13 & 61.20 & 61.31 & 67.16 & 67.44 \\
\hline $\begin{array}{l}\text { Predicted SY } \\
(\mathrm{t} / \mathrm{ha} / \mathrm{yr})\end{array}$ & 1.78 & 1.43 & 1.35 & 2.39 & 2.61 & 2.46 & 2.29 & 2.30 & 2.84 & 2.87 \\
\hline $\begin{array}{l}\text { Predicted SY } \\
\left(\mathrm{m}^{3} / \mathrm{ha} / \mathrm{yr}\right)\end{array}$ & 1.34 & 1.02 & 1.04 & 1.84 & 1.72 & 1.75 & 1.71 & 1.58 & 2.07 & 2.17 \\
\hline
\end{tabular}

In the MPSIAC model the minimum, average and maximum estimated sediment were, respectively, $1.02,1.62$ and $2.17 \mathrm{~m}^{3} /$ ha/year $( \pm 0.39)$. The skewness of data for the observed values was -0.08 , and for the estimated data was 0.42 , and correlation coefficient among the sediment data estimated from model and the observational data was equal to 0.47 . The estimated values had twice overestimation compared with the observed sediment.

Results of the estimated data from the three models of FSM, MPSIAC and PSIAC were compared with the observed sediment by the statistical method of relative error in equation (4), and the results have been reported in Table 7.

According to Table 7, the average observed sediment in 10 study watersheds was $0.74 \pm 0.42 \mathrm{~m}^{3}$. The minimum and maximum observed sediment were 0.41 and $1.18 \mathrm{~m}^{3} /$ ha/year, respectively.

As shown in Table 7, the relative error values in the FSM, PSIAC and MPSIAC models have been calculated 38.67, 2.35 and 1.22 with observational data, respectively. 
The relative error value closer to one indicates acceptable estimation of the model and vice versa. In this study, the FSM model with maximum relative error of 38.67 is far from observed data. The PSIAC model with overestimation of almost 2.35 for observed data showed better results compared with the FSM model and the estimated data of the MPSIAC model with the relative error of 1.22 had the lowest relative error compared to the two previous models as well as had the acceptable overestimation. The results correspond to previous findings, including Mohamadiha (2011), Atapourfard (2012), heravi et al. (2012), which confirmed overestimation for the FSM model. De Vente et al. 2005 pointed to the limitation of watershed areas between 10 and $10000 \mathrm{~km}^{2}$.

Table 7: Results of calculating relative error of FSM, MPSIAC and PSIAC models

\begin{tabular}{lccccccc}
\hline $\begin{array}{c}\text { small } \\
\text { catchments }\end{array}$ & $\begin{array}{c}\text { Measured } \\
\text { sediment yield } \\
\left.\mathrm{m}^{3} / \mathrm{ha} / \mathrm{y}\right)\end{array}$ & $\begin{array}{c}\text { FSM sediment } \\
\text { yield } \\
\left(\mathrm{m}^{3} / \mathrm{ha} / \mathrm{y}\right)\end{array}$ & $\begin{array}{c}\text { PSIAC } \\
\text { sediment yield } \\
\left(\mathrm{m}^{3} / \mathrm{ha} / \mathrm{y}\right)\end{array}$ & $\begin{array}{c}\text { MPSIAC } \\
\text { sediment yield } \\
\left(\mathrm{m}^{3} / \mathrm{ha} / \mathrm{y}\right)\end{array}$ & $\begin{array}{c}\text { FSM } \\
\text { relative error relative error }\end{array}$ & $\begin{array}{c}\text { MPSIAC } \\
\text { relative error }\end{array}$ \\
\hline Emamkandi & 0.93 & 23.25 & 2.27 & 1.34 & 24.00 & 1.44 & 0.44 \\
Silve1 & 0.87 & 31.31 & 1.72 & 1.02 & 34.99 & 0.98 & 0.17 \\
Silve2 & 0.41 & 33.90 & 1.68 & 1.04 & 81.68 & 3.07 & 1.54 \\
Ozondara1 & 1.18 & 75.38 & 2.54 & 1.84 & 62.88 & 1.15 & 0.56 \\
Ozondara2 & 0.57 & 26.37 & 2.67 & 1.72 & 45.26 & 3.67 & 2.02 \\
Ozondara3 & 0.87 & 25.88 & 2.59 & 1.75 & 28.75 & 1.98 & 1.01 \\
Kohnede1 & 0.49 & 14.31 & 2.34 & 1.71 & 28.20 & 3.78 & 2.49 \\
Kohnede2 & 0.56 & 15.12 & 2.17 & 1.58 & 26.00 & 2.88 & 1.82 \\
Khracho1 & 0.94 & 29.72 & 3.29 & 2.07 & 30.62 & 2.50 & 1.20 \\
Khracho2 & 1.11 & 28.08 & 3.37 & 2.17 & 24.30 & 2.04 & 0.95 \\
relative error & & 38.67 & 2.35 & 1.22 & & &
\end{tabular}

Based on the research findings in Iran, the efficiency of MPSIAC model has been confirmed by Tahmasebipoor and Najafi Disfani (1994), Nikjoo et al. (1995), Sokouti et al. (2005) and Bayat and Mahmoodabadi (2005). Brooshkeh et al. (2004) examined 25 small watershed sediments in West Azerbaijan province in Iran, who concluded that the average specific sediment yield and the highest measured sediment were, respectively, 1.3 and $12 \mathrm{~m}^{3} /$ ha/year for one of the watersheds with lithology sensitive to erosion and with rainfed lands. According to investigations of Toy et al. (2002), differences in measured soil loss from the same plot with erosion rates under one and 20 tons per hectare per year, were up to 400 percent and 30 percent, respectively. Nichols (2006) reported a 47-year long-term average sediment yield of the watershed with an area of 43.8 ha equal to 3 tons per hectare per year and the 10-year long-term average equal to 1.2 tons per hectare per year, representing major changes in sediment yield over time.

\section{CONCLUSIONS}

Regarding the mentioned items, we can concluded that the amounts of sediment and soil loss rate are the functions of various factors; and during the course of the investigation in relation to the reservoir sediment control has important role in determining sediment. If the duration of sediment yield behind 
the check dam is greater, the erosion and sediment will be measured with higher accuracy. Watersheds studied in this research had no much difference in terms of climatic conditions. However, lithological characteristics, type of land use and prevailing occupation in the region had major role in the sediment yield; the minimum and maximum observed sediment showed a three-fold difference.

Efficiency index of Nash and Sutcliffe for FSM, PSIAC and MPSIAC empirical models were, respectively, $-17386.37,-45.46$ and -11.48 . Base on the coefficient calculated, the FSM model showed high difference with the measured values and had no efficiency for small and several hundred hectares watersheds with primary coefficients. The efficiency index in the PSIAC model was better than the FSM model, but differed with measured sediment data; and its overestimation was 2.5 times. The index calculated in the MPSIAC model compared to the previous models had a better efficiency.

It is obvious that due to the intervention of various parameters in the sediment yield, certain values and ranges could not be declared with high confidence for sediment production in an area.

\section{REFERENCES}

Amin H., N. Honarjoo, A. Jalaiyan, M. Khalilzadeh, J. Baharlouie. 2014. A COMPARISON OF EPM AND WEPP MODELS FOR ESTIMATING SOIL EROSION OF MARMEH WATERSHED IN THE SOUTH IRAN. Agriculture \& Forestry, Vol. 60 Issue 4: 299-315, Podgorica

Atapourfard,A; Moradi Sharaf1, M; Shoaei2,G; 2012, The application of FSM model for the prediction of sediment yield in Tehran basinNature and Science;10(9) pages 105-112.

Bayat,R. and M. Mahmoodabadi. 2005. To determine the effect of MPSIAC and EPM parameters onthe estimation of deposition. National Conference of Erosion and Sedimentation, 253-250 (in Persian).

Brooshkeh, E., Sokuti Oskouei, R., Arab Khedri, M., and Habibi, M. 2004. Estimation of sediment yield of branches using measurement of sediment in small dams: A Case Study of selected branches in West Azerbaijan. The final report of the research project. Soil Conservation and Watershed Management Research Institute. 73 pages.

De Vente, J., J. Poesen \& G. Verstraeten. 2005. The application of semi-quantative methods and reservoir sedimentation rates for the prediction of sediment yield in Spain. Journal of Hydrology. 305: 63-86.

De Vente, J., J. Poesen., P. Bazzoffi., A. van Rompaey \& G. Verstraeten. 2006. Predicting catchment sediment yield in Mediterranean environments: the importance of sediment sources and connectivity in Italian drainage basins. Earth Surface Processes and Landforms. 31. 1017-1034.

Gasman, C; 2012, Assessment of uncertainties of soil erosion and sediment yield estimates at two spatial scales in the upperLiobregat at basin Cse pyrenees $\mathrm{B}$, arcelona spain.

Gholami, A; Mesri Alamdari, P. 2013 The Sensitivity Analysis and Efficiency of FSM and MPSIAC Models for Estimating Sediment Load,3rd International Conference on Civil, Transport and Environment Engineering (ICCTEE'2013)Dec. 25-26, 2013 Bangkok (Thailand.( 
Hadley, R. F., R. Lal, C. A. Onstad, D. E. Walling \& A. Yair. 1985. Recent developments in erosion and sediment yield studies. UNESCO. Paris. 127p.

Haregeweyn, N., J. Poesen, J. Nyssen, G. Verstraeten, J. D. Vente, G. Govers, S. Deckers and J. Moeyersons. 2005. Specific sediment yield in Tigray-Northern Ethiopia: Assessment and semi-quantitative modeling. Geomorphology. 69. pp: 315-331.

Heravi, H. et al. 2012. Application of FSM model in estimating soil erosion and sediment yield in Kan watershed. The First National Conference on Strategies to Achieve Sustainable Development. Tehran: Ministry of Interior.

Jhonson, C. W., Gembhart, A.C., 1982. Predicting sediment yield from Sagerbrush range lands. USDA SEAARM Western Series 26, 145-156

Khodami, M. 2005. Calculation of sediment yield using clay minerals and the application of complex multivariate linear methods in Lateshur watershed, northeast of Pakdasht. MA thesis. Ferdowsi University of Mashhad.

Mohamadiha1,S; Peyrowan2,H; Mousavi Harami3,R; Feiznia4,S; 2011, Evaluation of soil erosion and sediment yield using semi quantitative models: FSM and MPSIAC in Eivaneki watershed and the sub basins (Southeast of Tehran/Iran) Journal of American Science,; pages 234-239.

Moore, R. E. Kearfott, R. B. and Cloud, M. J. Introduction to Interval Analysis, SIAM Press, hiladelphia, Pennsylvania, 2009.

Nash, J.E. and Sutcliff, J.V, 1970. River flow forcasting through conceptual model. Part I : discussion of principles . hydro 1 10: 282-290

Neil, D. T. 1988. Generalization of a system for estimating small catchment's.

Nikjoo, M., A. Ahmadi and A. javanshir. 1995. Evaluation of PSIAC models in estimating erosion and sediment of Daryanchai basin. MSc Thesis, Tarbiat Modares University, 229 pages (in Persian).

Pourkarimi M., Mahmoudi S., Masihabadi M., Pazira E., Moeini A.(2017): Use of MPSIAC and EPM to estimate sediment yield and erosion - a case study of a watershed of the second urban phase, Mashhad, Khorasan province. Agriculture and Forestry, 63 (4): 201-213. DOI:10.17707/AgricultForest.63.4.21

Refahi H.Control of water erosion, Tehran university publications.2009: pp. 550.

Sokouti, R., M. Arabkhedri, J. Ghoddosi and E. Brooshkeh. 2005. Calibration of MPSIAC model for estimating sediments. Final research report, Soil Conservation and Watershed Management Research Institute, 51 pages (in Persian).

Tahmasebipoor, N. and M. Najafi Disfani. 1994. Application and evaluation MPSIAC model for mapping erosion and sediment at Lork basin with the use of satellite images and geographic information systems. MSc Thesis, Tarbiat Modares University, 185 pages (in Persian).

Verstraeten, G., J. Poesen, J. de Vente \& X. Koninckx.2003.Sediment yield variability in Spain:A quantitative and semiqualitative analysis using reservoir sedimentation rates. Geomorphology. 50 (4) 327-348. 